Pamiętnik Literacki 2015, 4, s. 255-257

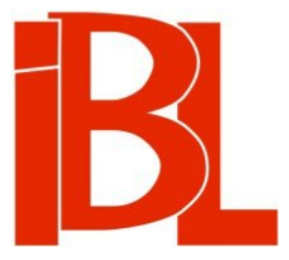

\title{
Hanna Dziechcińska
}

(21 stycznia 1924-26 sierpnia 2015)

Wspomnienie

Joanna Partyka 
HANNA DZIECHCIŃSKA (21 stycznia 1924 - 26 sierpnia 2015) WSPOMNIENIE

8 czerwca 2015 w Instytucie Badań Literackich PAN odbyła się polsko-włoska konferencja zatytułowana "Inna komparatystyka”. Od dokumentu do wyobraźni. Wzięli w niej udział włoscy poloniści oraz polscy badacze zainteresowani polsko-włoską komparatystyką literacką. Spotkanie przygotowane zostało z myślą o prof. Hannie Dziechcińskiej i jej zadedykowane. Choć Pani Profesor miała już 91 lat, zapewne nikt nie spodziewał się w tym momencie, że będzie to także pożegnanie... Pożegnanie $z$ człowiekiem, a zarazem $z$ wciąż piszącą badaczką literatury i kultury dawnej, która do końca publikowała swoje prace. Nie zawsze udaje się zdażyć z takim pożegnaniem. Profesor Dziechcińska zmarła w niespełna trzy miesiące później, 26 sierpnia.

Przez całe życie związana była $z$ Instytutem Badań Literackich. Pracę naukową w IBL rozpoczęła 1 stycznia 1953 na stanowisku asystenta w Pracowni Literatury Staropolskiej, tu w 1963 r. obroniła rozprawę doktorska (Proza staropolska. Problemy gatunków i literackości, wyd. 1967), pisaną pod kierunkiem Kazimierza Budzyka, 8 lat później została doktorem habilitowanym, a ukoronowaniem kariery naukowej było otrzymanie w r. 1991 tytułu profesora zwyczajnego. Przejście na emeryture jedynie zintensyfikowało jej działalność naukowa, co wydaje się paradoksem. Życie prof. Hanny Dziechcińskiej przepełniały tego rodzaju paradoksy: nigdy nie nauczyła się posługiwać komputerem, choć podejmowała takie próby, i nie korzystała $z$ Internetu, a przy tym była osoba pod wieloma względami niezwykle nowoczesna, kiedy pisała (ręcznie lub na maszynie) o kulturze i literaturze. Miała niebywałą intuicję w wyszukiwaniu tematów ważnych, interesujących, zarazem zaś pozwalających, co było bardzo cenne, włączyć polską kulturę w krąg myśli europejskiej. Zajmowała się komparatystyką literacką w czasach, gdy nie było to jeszcze tak popularne w Polsce jak obecnie.

Jej pierwszą fascynację naukową stanowiła staropolska kultura rękopisu. Trudno sobie dziś wyobrazić jakiekolwiek opracowanie traktujące o kulturze polskiej dawnych wieków bez odniesień do zbiorowej monografii pod tym właśnie tytułem, która była rezultatem zaplanowanej i zorganizowanej przez nią w r. 1988 konferencji. Rok później ukazał się tom zbiorowy pod jej redakcją: Kultura żywego słowa $w$ dawnej Polsce. Plonem kolejnej konferencji, której pomysłodawczynią była także prof. Dziechcińska, stał się równie cenny tom, zatytułowany Literatura $i$ instytucje $w$ dawnej Polsce (1994). Książki takie, jak Literatura a zabawa. $Z$ dziejów kultury literackiej $w$ dawnej Polsce (1981) oraz Ogladanie i stuchanie $w$ kulturze dawnej Polski (1987), wydane w charakterystycznej serii „Z Bakałarzem”, sa do dziś ważnymi pozycjami w warsztacie polonisty staropolanina. Swego czasu otworzyły one polonistom - wykładowcom i studentom - całkiem nowe przestrzenie 
badawcze, zachęcając do innego nieco spojrzenia na kulturę epok dawnych. Trudno je przecenić.

Hanna Dziechcińska wiele artykułów i trzy książki (O staropolskich dziennikach podróży, 1991; Pamiętniki czasów saskich. Od sentymentalizmu do sensualizmu, 1999; Świat i człowiek $w$ pamiętnikach trzech stuleci: XVI-XVII-XVIII, 2003) poświęciła podróżom. Fascynowało ją zjawisko podróżowania w dawnych epokach, miejsce podróży w świadomości społecznej. Sama też lubiła podróżować - w celach turystycznych, ale przede wszystkim naukowych. Już pierwszy wyjazd stypendialny na kwerendę do Włoch w r. 1986 zaowocował nawiązaniem współpracy z Pietrem Marchesanim. Z czasem prof. Dziechcińska zyskała sobie wielu przyjaciół w gronie włoskich polonistów i slawistów (były to m.in. prof. prof. Giovanna Brogi, Marina Ciccarini i Giovanna Tomassucci, uczestniczki czerwcowej konferencji), którzy zawsze mogli liczyć na jej merytoryczną pomoc i współpracowali z nia przy realizacji różnych tematów badawczych. Sama też od nich sporo się uczyła, zdając sobie świetnie sprawę $z$ tego, że polonista-cudzoziemiec dostrzega w kulturze staropolskiej kwestie, na które polski badacz nie zwróciłby uwagi. Takie spostrzeżenie przyświecało zapewne prof. Dziechcińskiej, gdy postanowiła wydać (wraz z Ewą Jolantą Głębicką) zbiór artykułów wybitnego polonisty belgijskiego Claude’a Backvisa ksiażka Renesans $i$ barok w Polsce. Studia o kulturze ukazała się w 1993 roku. Dziechcińska dzieliła się też swoją wiedzą z zagranicznymi studentami - w r. 1990 prowadziła zajęcia dydaktyczne na uniwersytecie w Nanterre. Warto zauważyć, że w czasach, gdy ścisła współpraca naukowa $z$ zagranica nie miała jeszcze takiego znaczenia jak dziś, Hanna Dziechcińska systematycznie redagowała i oddawała do druku kolejne tomy publikacji seryjnej „Literary Studies in Poland / Études Littéraires en Pologne”. W latach 1978-1992 wyszło 26 tomów tego półrocznika, który zaznajamiał europejskich badaczy z tym, co i jak się pisze o polskiej literaturze.

20 ostatnich lat to kolejne prace prof. Dziechcińskiej: Ciało, strój, gest w czasach renesansu i baroku (1996), Kobieta $w$ życiu i literaturze XVI i XVII wieku. Zagadnienia wybrane (2001), Przeszłość i teraźniejszość w kulturze czasów saskich (2007), Sztuka przekonywania $w$ kulturze polskiej trzech stuleci: XVI-XVII-XVIII (2010). Każda $\mathrm{z}$ tych książek spotkała się $\mathrm{z}$ dużą przychylnością czytelników.

Prof. Dziechcińska była przede wszystkim badaczem, w mniejszym stopniu dydaktykiem, choć potrafiła przekazać swoją pasję młodym pokoleniom staropolan. Byłam jej doktorantką i dużo jej zawdzięczam. Umiejętnie i cierpliwie uczyła mnie, jak pisać o dawnej kulturze, by zainteresować dzisiejszych czytelników. Zawsze ważne było dla niej to, żeby tekst naukowy trafiał do szerokiego grona odbiorców, nie tylko do badaczy. Będąc już na emeryturze, bardziej zaangażowała się w dydaktykę, wykładając w Szkole Wyższej Przymierza Rodzin i w Warszawskiej Wyższej Szkole Humanistycznej im. Bolesława Prusa.

Hanna Dziechcińska miała przyjaciół wśród młodych badaczy. Zachwycała radością życia, niespożytą energią i szczególnym rodzajem dowcipu. Rozmawiało się $z$ nią na różne tematy, zadziwiała jasnością sądów i osądów, potrafiła być krytyczna. Należało się do tego przyzwyczaić. Kontakty z nią nie zawsze były łatwe, ale przynosiły wiele korzyści naukowych i wiele uczyły.

Dwa lata temu ukazała się jej ostatnia praca: Mowa uczuć. $Z$ dziejów powieści 
polskiej XVII i XVIII wieku. Za symboliczny można uznać fakt, że książka wyszła w Wydawnictwie Instytutu Badań Literackich, z którym do końca Dziechcińska była związana. Marek Prejs w recenzji wydawniczej napisał o tej rozprawie: „Stanowi ona ważny głos w dyskusji dotyczącej genezy i odrębności polskiej powieści nowożytnej. Jest przy tym erudycyjnym podsumowaniem wieloletnich badań samej autorki”. Prof. Hanna Dziechcińska wybierając tematy swych kolejnych książek -

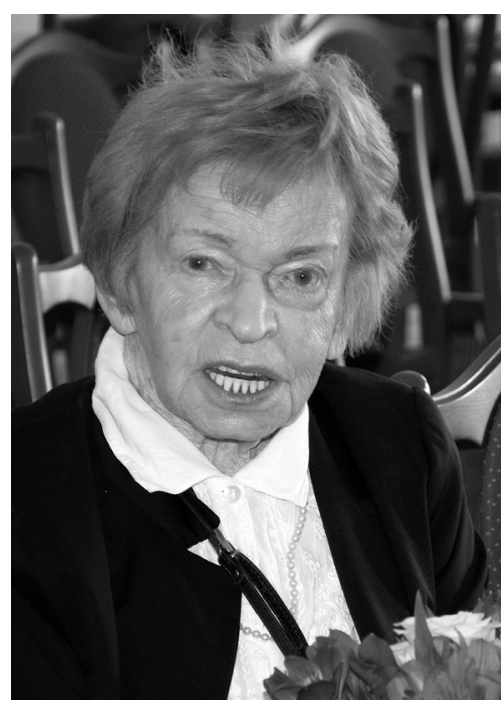

Hanna Dziechcińska

Fot. Lidia Bakensztos

które nigdy nie były wielkimi woluminami, ale zawierały cały ogrom erudycyjnych spostrzeżeń - systematycznie uzupełniała luki w badaniach nad literatura i kulturą epok dawnych. To jej zawdzięczamy. I musimy zaakceptować fakt, że czerwcowa konferencja była pożegnaniem...

Joanna Partyka

Instytut Badań Literackich PAN - Institute of Literary Research of the Polish Academy of Sciences, Warsaw

Abstract

\section{OBITUARY: HANNA DZIECHCIŃSKA}

A remembrance about a lately deceased eminent literature and culture in old Poland scholar as well as a researcher in comparative literary studies. 